\author{
U.M. Abdigapbarova*, N.B. Zhienbaeva \\ Abai Kazakh National Pedagogical University, Almaty, Kazakhstan \\ (Corresponding author's E-mail:abdigapbarova_um@mail.ru)
}

\title{
Social activity of the future teacher's personality in the process of SCL transformation
}

\begin{abstract}
This article reveals the transformation of student-centered learning (SCL) in the process of forming the social activity of Kazakhstani students, which is a fundamental aspect that has an effective impact on the professional training of future teachers. The author substantiates the fact of the importance of the social activity of the modern student, the success factor of student-centered learning: emotional support and psychological support of teachers to improve the educational potential of student-centered learning. The conceptual provisions of the features of the introduction of student-centered learning in the educational process of higher educational institutions of the Republic of Kazakhstan are argued. Based on a comprehensive analysis it is proved that the distinctive feature of a high-quality university is the success of the process of implementing student-centered learning, where the most important role belongs to teachers and students. A personalized form of student-centered learning in a digital environment is presented. The content aspects of the personalized development of the student's personality and the orientation of the tutor-facilitator functionality of the higher school teacher are developed.
\end{abstract}

Keywords: professional training of the future teacher, SCL-student-centered learning, transformation of student-centered learning, personalized form of learning, social activity, communication, digitalization, digital environment.

\section{Introduction}

The humanistic meaning of social transformations in modern Kazakhstan is the recognition of a person as the highest value of society, the harmonization of public and the personal interests and creating conditions for the development of an active and creative personality.

Due to the multi-level educational organization of the modern student, the improvement of the system of training of these subjects is based on the existence of two priority areas: training and education.

The essence of the modernized system of teacher education is the need to train a new teacher. The new teacher is a socially active representative of the Kazakh society with a high level of national identity, professionalism and competitiveness.

\section{Main body}

It could be stated that the teacher training system does not consider the features of education based on the socially active generation of future teachers. We believe that the social activity of the future teacher should be considered in relation to initiative, efficiency, the responsibility of the activity of the individual (its main components), the functions of which are manifested in the process of solving socially significant social tasks.

At the present stage the main characteristic of personal activity is the measure of the value of a person's contribution to the solution of social problems, which allows us to distinguish their social activity in a holistic characteristic of a person's personality and activity. K.A. Abulkhanova-Slavskaya proposed this consideration of the social activity of the individual.

A detailed analysis of activity as psychodynamic characteristics of human behavior is given in the works of such various psychologists as J. Gilford, J. Strelau, G. Heymans, E. Fersman, A.I. Krupnov, V.S. Merlin, V.D. Nebylitsyn, V.M. Rusalov, etc.
L.S. Vygotsky,
A.N. Leontiev,
S.L. Rubinstein,
A.G. Asmolov,
V.D. Shchadrikov, D.B. Bogoyavlenskaya and others considered the activity of the individual through the analysis of motivational and operational components within the framework of the personal activity approach, aimed at achieving the goal. 
It is known that social activity manifests itself directly in the activity. It should be noted here that: in methodological terms, activity can be a form of activity, and the activity itself can be described through the measure of the activity of the individual. A person can be passive, i.e., not to develop external and internal activities, and active, i.e., to initiate their own actions, intensively implement them and achieve high results.

For psychological science, the traditional approach is one that asserts the principle of activity. The works of L.S. Vygotsky, F.F. Dobrynin, S.L. Rubinstein, A.N. Leontiev, S.D. Smirnov and others played an important role here. In recent years an attempt to formulate the principle of activity has been made by the psychologist S.D. Smirnov, who writes: "Activity acts as one of the constitutive characteristics of human activity, expressing the ability for self-development, self-movement through the initiation of purposeful creative objective actions by the subject. At the same time, the goals and means of activity are the source of events that grow out of the life context, the content of which is formed by relationships with other people" [1: 103].

The importance of this principle is difficult to overestimate for understanding the essence of the activity of the human personality. Its application makes it possible to reveal the creative, transformative nature of human activity. Activity reveals the dynamic features of the psyche, its content aspects, and finally, the quality of the results achieved by a person. In each case the activity acquires its own identity and through this characterizes the human psyche as a complex multi-level formation.

However, before proceeding to the analysis of activity in its various manifestations it is necessary to focus on one more problem, namely, the problem of the sources of personal activity themselves. The source of the activity of the individual is the needs that determine the activity through the corresponding motives, providing it with a certain direction.

We believe that the measure that determines the nature of active student-centered learning is digitalization, which will be considered from the point of view of the value goals the student sets and achieves, and which, in turn, are an integral element that has a positive impact on the professional training of the future teacher of digital Kazakhstan

We are impressed by the consideration of the issue of «social task» in the works of K.A. AbulkhanovaSlavskaya. In her opinion, the social task acts as a specific form of inclusion of the individual in the activity: "It is a form of organization of restriction and at the same time actualization of his activity, a form with definitions and renewal" [2: 187]. The value of the introduction of this concept is that "it is a transition from the definition of the individual through public entity (public relations) to determine its using method of implementation essence" [2: 188].

In exploring the psychological nature of the social activity, we base our work on the principle of activity in defining the concept of communication. Namely, the motives of the subject's activity determine the selectivity and activity of communication [3: 287].

Based on the multi-level structure of a person as an organism, a social individual and a personality, activity considered for that reason. We convincingly reveal the activity of the personality of the modern future teacher through cognitive characteristics, and most importantly, as a measure of values, and contributions to solving the most important tasks set by society.

The activity of communication is an integral part of the communication process as a whole. This phenomenon is characterized by internal and external contradictions, the needs and characteristics of the individual, the level of attitudes, beliefs, value orientations on the one hand, and the changes that occur in the social environment, on the other. In this case, it is the digitalization of Kazakhstan's education. Internal and external contradictions arise and are resolved in the process of interaction of the subjects of the educational process in the digital environment.

Thus, by the communication activity we mean the mental or real direction of the individual's influence on another person in order to obtain information, influence, subordinate, control, change attitudes.

Student-centered learning, based on the scientific research of foreign researchers, represents the holistic cultural and civic position of a modern university.

The transformation of student-centered learning in the light of the competence approach implies the importance of critical study and understanding the future teacher as the central figure of the educational process, whose interests and educational needs should lead to the improvement of methodological, organizational and technological support for personalized learning in a digital environment. The reform of educational programs should enable high quality, flexible and individualized educational trajectories. However, student-centered learning is not limited to a specific methodology; rather, it is a sociocultural change in the university. 
In our previous work, we have emphasized the fundamental principles of the SCL such as:

- students should show an active role in learning;

- the student is fully responsible for their education;

- engagement and participation are essential elements of learning;

- relations between students are equal, which contributes to growth and development;

- teacher is a facilitator-tutor;

- merging of the affective and cognitive spheres of the psychological essence of the student's personality.

The successful use of the pedagogical potential of the university and its role in the transformation of student-centered learning are the need to apply its professional and personal resources in using the procedures of pedagogical design; improving the practice of preparing and planning the educational and digital environment. Therefore the most important task of a teacher is to teach students to independently manage their educational activities, to activate the process of self-improvement of the individual, to develop selfregulation, self-organization, and self-control. Meanwhile, it is necessary to form individual styles and strategies for students' learning activities.

Improving pedagogical skills in the university training of future teachers means multi-level updating of educational results, the content of transformed student-centered learning; technologies and organizational forms of the educational process; academic self-assessment and evaluation of the results achieved in an actively developing digital environment to improve radically educational results. Academic self-assessment is one of the main characteristics of improving pedagogical skills and it contains a cognitive representation of the perceived abilities of the teacher and the student in the situation of academic achievements. It is important for learning outcomes that intrinsic motivation related to the perceived competence of the future teacher and supported by skill selection, complex tasks and feedback postulate the causal influence of the academic self-conception on intrinsic motivation.

For example, the American scientists A. Newell and H. Simon, who are engaged in heuristic programming, state that "if we can create a program that, when implemented on computers, well simulates human behavior, we can consider that we have discovered a system of mechanisms at least sufficient to ensure this behavior" $[4,5]$.

The reform of educational programs should ensure the possibility of high quality, student-centered, and personalized educational trajectories [6].

Personalization is the foundation of student-centered learning involves a high degree of student engagement, shifting the focus of responsibility and expectations to each student's strengths and weaknesses, and then shaping content to meet these needs. Personalized learning should lead to the development of methodological and organizational support, as well as a change in the role of a teacher. A pilot study by J. Sanchez, A. Salinas showed that students need psychological and pedagogical support for personalized learning in a digital environment [7]. This is also confirmed by the research of S.L. Loginova: "emotional support and psychological support of teachers turned out to be a significant factor in the success of training for students" [8].

Research devoted to the theoretical and scientific-practical developments of student-centered learning (SCE):

1. SCL is associated with constructivist paradigms, theories, learning concepts based on the philosophy of innovative thinking and the digital culture of the university [9].

2. The holistic design of the SCL: advantages for the subjects of the educational process in the context of the Bologna Declaration [10].

3. Priority and effectiveness of student-centered learning for the European Higher Education Area.

4. Creating psychological conditions, health-saving technologies for the transformation of studentcentered learning. Using innovative methods and a supportive learning environment to engage students and teachers in the management of educational programs at all levels.

5. When implementing transformed student-centered learning in a digital environment, pedagogical universities are recommended to ensure an active position of students in the design of educational programs [11].

In foreign sources SCL is interpreted in the same way as in domestic studies, namely as a method of learning and teaching, in the center of which the student is located.

The concept of student-centered learning (SCL) F. Hayward, D. Dewey, K. Rogers, M. Knowles, J. Piaget $[12,13,14,15]$; theoretical foundations of the concept of student-centered approach 
(L.S. Vygotsky, V.V. Davydov, P.Ya. Galperin, E.V. Bondarevsky); student-centered approach in teaching as the main principle of higher education (V.I. Baydenko, N.A. Selezneva, M.A. Akopov); productive approaches to providing the theoretical and technological basis for training specialists in the conditions of a university (A.A. Verbitsky, E.S. Polat, M.I. Ragulina); education in the digital age (A. Marey, T.V. Nikulina, S.L. Loginova, A.B. Sobolev, N.Yu. Ignatova) [16].

The analysis of the researches allowed us to draw the following conclusions:

- student-centered learning is aimed at overcoming the problems associated with traditional forms of education, focused on the students and their needs, and based on the interaction of subjects of the educational process; if the best possible conditions for the development of the participants are created in this process the ability of self-education, self-determination, autonomy, and self-realization enters the sphere of professional activity;

- student-centered learning requires a constant reflexive process, it does not have a single solution suitable for all cases; students adhere to different learning styles; the choice is essential for the effectiveness of student-centered learning; students have different experiences and basic knowledge; students are called upon to control their learning; student-centered learning means "creating opportunities", not "informing"; learning requires cooperation between students and teachers;

- in the process of implementing student-centered learning students develop competence in the field of independent cognitive activity based on the assimilation of ways to acquire knowledge from various sources of information, competence in the field of civil and social activities, social and labor activities.

Student-centered learning is not limited to a specific methodology, rather it is a cultural change in the university. It also builds on the successful implementation of the Bologna processes, such as recognition procedures and ECTS based on learning outcomes. Current quality assurance mechanisms highlight the importance of teaching (teacher-student interaction, students as knowledge creators and members of the academic community, curriculum development regarding learning outcomes), however, they have their limitations.

A program-level assessment can provide more insight into the methodological structure of a particular educational program. However, institutional evaluations performed by quality assurance agencies rarely take teaching and learning as the main aspects, which gives a false signal to the university management about the priorities of management. In fact, it means that research activity is rewarded significantly more than highquality teaching, and teachers have little incentive to develop their teaching skills, apply and evaluate new teaching methods, such as inquiry-based learning and project-focused activities. At the same time, little practice focuses on students and encourages them to take a more active role in developing their learning path, take advantage of collaborative learning methods, and develop critical thinking while questioning established knowledge.

The analysis of the works of Kazakhstani scientists showed the lack of research on student-centered learning (SCL) in relation to higher education.

The fundamental research of the President of IQAA Sh.M. Kalanova "Student-centered learning, teachingand evaluation: basic principles, parameters, and conditions" is the starting point, the key basis for the current stage of education, the implementation of student-centered learning in Kazakhstan's higher education institutions. Grounded positions on the peculiarities of implementation of SCL in the educational process of higher educational institutions of the Republic of Kazakhstan, evaluation of the implementation of student-centeredness in the process of accreditation of the universities are the theoretical and methodological basis of student-centered learning. The Independent Agency for Quality Assurance in Education, IQAA (NAOKO), aims at the creation of the educational community that succeeds in of the process of implementing SCL, considers it as the distinctive feature of a high-quality university, where the most important role belongs to teachers and students.

Special emphasis is placed on the fact that the SCL does not contain and does not offer a universal approach or answer due to the need for a continuous process of reflection and flexibility in the implementation of the SCL. The point of the SCL is to create opportunities, not to inform. The key aspects of SCL have generally recognized a thorough approach to the learning process with an emphasis on critical and analytical study and understanding, increased autonomy, the responsibility of students; a reflexive approach to the teaching and learning processes [17].

The lack of evidence-based concepts of student-centered learning transformation of subjects of the educational process of the university in the context of the ideas of digital society is what defines the relevance and the specific semantic content of the input in the scientific and pedagogical terminology, i.e., the terms 
"transformation of student-centered learning", "personalized form of learning in the digital environment". Nowadays there is an increase of activity of Kazakhstani scientists and practitioners in discussing and addressing the problem of student-centered learning as a reflection of modern approaches to higher education and involves the use of interactive teaching methods, emotional and communicative involvement of students in the educational process of the university.

However, insufficient attention is paid directly to the implementation of the student-centered principle in higher pedagogical education of the Republic of Kazakhstan, despite the fact that the design of educational programs was recognized as fundamental in the Bologna reforms. Meanwhile, the demand and relevance of its implementation are acute. A modern university needs to strengthen the criteria that determine the professionalism of a teacher, the willingness to use innovative teaching technologies and knowledge control in the context of student-centered learning.

Current situation in higher pedagogical education dictates the need to introduce the most productive technologies that significantly increase the professional and practical competence of future teachers, such as a personalized form of learning in the digital environment as the basis for transformed student-centered learning. An innovative program for transforming student-centered learning into the process of preparing a future teacher in a digital environment will help to increase the motivation of graduates of pedagogical universities to acquire a teaching profession.

The need for the project from the standpoint of queries teaching practice is determined by the importance of restructuring the professional consciousness of future teachers in order to improve their competitiveness, increase the number of employed graduates of pedagogical universities. From the point of view of the requirements of pedagogical science the project is necessary for the development of modern approaches to teacher training in line with the modernization of the system of higher pedagogical education of the Republic of Kazakhstan.

\section{Conclusion}

The development of scientific and practical foundations of student-centered learning as a pedagogical paradigm of digital actualization of the process of professional training of future teachers involves the use of methods of theoretical analysis and generalization of sociological, psychological, and pedagogical research.

The philosophy of student-centered learning consists in that teachers and students should constantly reflexively consider their teaching, learning, and infrastructure systems in such a way as to: actualize students' learning experiences, ensure the achievement of planned learning outcomes and stimulate critical thinking. In the joint mission, students were and should remain the center of the educational process with the full involvement of stakeholders.

The mechanism of transformation of student-centered learning in process request internal training of the future teachers in the digital environment, and allows to present the algorithm of development of interaction of subjects of the educational process of the University, submitted by the unity of methodological approaches (activity and competence); the essential core (representing the characteristics of the relationship of objective and subjective, external and internal factors of development of subjects of interaction, actual or potential, actual and possible); a set of laws and their corresponding general and specific principles.

\section{References}

1 Смирнов С.Д. Психология образа: проблема активности психического отражения / С.Д. Смирнов. — М., 1985. $278 \mathrm{c}$.

2 Абульханова-Славская К.А. Проблема активности личности, методология и стратегия исследования / К.А. Абульханова-Славская // Активность и жизненная позиция личности. - М., 1988. - 315 с.

3 Ананьев Б.Г. О проблемах современного человекознания / Б.Г. Ананьев. - М.: Наука, 1977. — 388 с.

4 Newell A., Manual. Intellegence Scale for children. - N.Y., 1989.

5 Simon H.A., Dearborn D.C. (1978). Selective perception. A hote on the departmental identification of executive / H.A. Simon, D.C. Dearborn // Sociometry. - Vol. 21. - P. 140-144.

6 Государственная программа развития образования и науки Республики Казахстан на 2020-2025 гг. Постановление Правительства РК от 27 декабря 2019 года № 988. [Электронный ресурс]. — Режим доступа: https://adilet.zan.kz/

7 Sánchez J. Does the new digital generation of learners exist (2011). A Qualitative Study [Electronic resource] / J. Sánchez, A. Salinas, D. Contreras, E. Meyer // British journal of educational technology. — № 42 (4). — P. 543-556. — Access mode: https://www.researchgate.net/ publication/227793574 
8 Логинова С.Л. Цифровизация высшего образования: основные противоречия / С.Л. Логинова // Непрерывное образование: теория и практика реализации: материалы II Междунар. науч.-практ. конф. / С.Л. Логинова. — Екатеринбург, 2019. C. 104-107.

9 The European Higher Education Area in the new Decade. Communique of the Conference of European Ministers Responsible for Higher Education, Leuven and Louvain-la-Neuve [Электронный pecypc]. - Режим доступа: https://www.eurashe.eu/library/modernisingphe/Bologna_2009_Leuven-Communique.pdf

10 Коммюнике Конференции министров Европейского пространства высшего образования, г. Бухарест, Румыния, 2627 апреля 2012 г. [Электронный ресурс]. - Режим доступа: http://www.bsu.by/Cache/Page/172203.pdf

11 Report of the European Commmission «Improving the quality of teaching and learning in Europe's higher education institutions» [Электронный ресурс]. — Режим доступа: http://ec.europa.eu/dgs/education_culture/repository/education/library/reports /modernisation en.pdf

12 Rogers C.R. Freedom to Learn for the 80's. / C.R. Rogers // Columbus Charles Merrill Publishing Company, 1983. — 312 p.

13 Knowles M.S. Self-Directed Learning: a Guide for Learners and Teachers / M.S. Knowles. - N.Y.: Association Press, 1975. $-135 \mathrm{p}$.

14 Пиаже Ж. Психология интеллекта / Ж. Пиаже. - М.: Питер, 2004. — 192 с.

15 Марей А. Цифровизация как изменение парадигмы /А.Марей [Электронный ресурс]. — Режим доступа: https://www.bcg.com/ru-ru/about/bcg-review/digitalization.aspx.

16 Соболев А.Б. Меняйся или уходи. Цифровое образование бросает вызов преподавателям вуза [Электронный ресурс] / А.Б. Соболев // Электрон. газета «Поиск». — 2018. — № 1, 2. — Режим доступа: http://www.poisknews.ru/theme/edu/31969/.

17 Каланова Ш.М. Национальная система и образовательные стандарты высшего образования в Республике Казахстан: нац. докл. / Ш.М. Каланова. — 2-е изд., перераб. и доп. — М.: ИЦПКПС, 2009. — 117 с.

\author{
¥.М. Әбдіғапбарова, Н.Б. Жиенбаева
}

\title{
Студентке орталықтандырылған оқытуды трансформациялау үрдісінде болашақ мұғалім тұлғасының әлеуметтік белсенділігі
}

\begin{abstract}
Мақалада студент жастардың әлеуметтік белсенділігін қалыптастыру контексінде белсенді өзгерістер студентке орталықтандырылған оқытудың (СОO) сипатын айқындайтын проблемалар қарастырылды, яғни ол өз кезегінде цифрлық Қазақстанның болашақ мұғалімінің кәсіби даярлығына оң әсер ететін ажырамас элементі болып табылады. Қазіргі студентке орталықтандырылған оқытудың табысқа жету факторының бірі - студенттің әлеуметтік белсенділігінің маңыздылығы. СОО білім беру әлеуетін жақсарту үшін оқытушыларға эмоционалды және психологиялық қолдау көрсетілу қажеттілігі талданды. Қазақстан Республикасының жоғары оқу орындарының білім беру үрдісіне студентке орталықтандырылған оқытуды енгізу ерекшеліктерінің тұжырымдамалық ережелері дәлелденді. Кешенді талдау негізінде студентке орталықтандырылған оқытуды енгізу үдерісінің нәтижелілігі университеттің жоғары сапалылығымен ерекшеленуінен талап етілетіндігі көрсетілді. Мұнда оқытушылар мен студенттер рөлі аса маңыздылыққа ие. Цифрлық орта жағдайында студентке орталықтандырылған оқытудың жеке формасы ұсынылды. Студент тұлғасының дербестендірілген дамуының және жоғары мектеп оқытушысының тьюторлық-фасилитаторлық функционалдық бағыттылығының мазмұндық аспектілері әзірленді.
\end{abstract}

Кілт сөздер: болашақ педагогтің кәсіби даярлығы, студентке орталықтандырылған оқыту, студентке орталықтандырылған оқытуды трансформациялау, оқытудың персональды формасы, әлеуметтік белсенділік, коммуникативтік қарым-қатынас, цифрландыру, цифрлық орта.

\section{У.М. Абдигапбарова, Н.Б. Жиенбаева \\ Социальная активность личности будущего учителя
в процессе трансформации студентоцентрированного обучения}

В статье рассмотрены проблемы, определяющие характер активного трансформированного студентоцентрированного обучения (СЦО), в контексте формирования социальной активности студенческой молодежи, которая, в свою очередь, является неотъемлемым элементом,оказывающим положительное влияние на профессиональную подготовку будущего учителя цифрового Казахстана. Обоснован факт значимости социальной активности современного студента, фактор успешности СЦО: эмоциональная поддержка и психологическое сопровождение преподавателей для совершенствования образовательного потенциала СЦО. Аргументированы концептуальные положения особенностей внедрения студентоцентрированного обучения в образовательный процесс высших учебных заведений Республики Казахстан. На основе комплексного анализа доказано, что отличительной чертой высококачественного вуза является успешность процесса внедрения студентоцентрированного обучения, где важнейшая роль принадлежит преподавателям и студентам. Представлена персонализированная форма студенто- 
центрированного обучения в условиях цифровой среды. Разработаны содержательные аспекты персонализированного развития личности студента и направленности тьюторско-фасилитаторского функционала преподавателя высшей школы.

Ключевые слова: профессиональная подготовка будущего учителя, студентоцентрированное обучение, трансформация студентоцентрированного обучения, персонализированная форма обучения в цифровой среде.

\section{References}

1 Smirnov, S.D. (1985). Psikhologiia obraza: problema aktivnosti psikhicheskogo otrazheniia [Examples the problem of the activity of mental reflection]. Moscow [in Russian].

2 Abulkhanova-Slavskaya, K.A. (1988). Problema aktivnosti lichnosti, metodologiia i strategiia issledovaniia [The problem of personality activity, methodology and research strategy]. Aktivnost $i$ zhiznennaia pozitsiia lichnosti - Activity and the life position of the individual, 315. Moscow [in Russian].

3 Ananyev, B.G. (1977). O problemakh sovremennogo chelovekoznaniia [The problems of modern human knowledge examples]. Moscow: Nauka [in Russian].

4 Newell, A. (1989). Manual. Intelligence Scale for children [Intelligence Scale for children]. New York.

5 Simon, H.A., \& Dearborn, D.C. (1978). Selective perception. A note on the departmental identification of executive. Sociometry. The departmental identification of executive, Vol. 21, 140-144.

6 Gosudarstvennaia programma razvitiia obrazovaniia i nauki Respubliki Kazakhstan na 2020-2025 gody. Postanovlenie Pravitelstva RK ot 27 dekabria 2019 goda No. 988 [State Program for the Development of Education and Science of the Republic of Kazakhstan for 2020-2025. 2019]. (2019 december). Retrieved from https://adilet.zan.kz/ [in Russian].

7 Sanchez, J., Salinas, A., Contreras, D. \& Meyer, E. (2011). Does the new digital generation of learners exist. A Qualitative Study [British journal of educational technology]. Does the new digital generation of learners exist, Vol. 42, 543-556. Retrieved from https://www.researchgate.net/ publication/ 227793574.pdf. San Francisco, CA.

8 Loginova, S.L. (2019). Tsifrovizatsiia vysshego obrazovaniia: osnovnye protivorechiia [Digitalization of higher education: the main contradictions]. Continuing education: theory and practice of implementation: materialy II Mezhdunarodnoi nauchnoprakticheskoi konferentsii - Materials of the II International Scientific and Practical Conference (15 iiunia 2019 hoda). (p. $104-$ 107). Yekaterinburg [in Russian].

9 The European Higher Education Areain the new Decade (accessed 17.06.2017) Communiqué of the Conference of European Ministers Responsible for Higher Education, Leuven and Louvain-la-Neuve. eurashe.eu. Retrieved from https://www.eurashe.eu/library/modernisingphe/ [in Bologna].

10 Kommiunike Konferentsii ministrov Evropeiskoho prostranstva vysshego obrazovaniia [Communique of the Conference of Ministers of the European Higher Education Area]. [n.d.]. bsu.by. Retrieved from http://www.bsu.by/Cache/Page/172203.pdf (date accessed: 17.06.2017). Bucharest [in Russian].

11 Report of the European Commission "Improving the quality of teaching and learning in Europe's higher education institutions". (accessed 17.06.2017). [n.d]. ec.europa.eu. Retrieved from http://ec.europa.eu/dgs/education_culture/ repository/education/library/reports/modernisation.pdf. Bucharest [in Romania].

12 Rogers, C.R. (1983). Freedom to Learn for the 80's. Columbus Charles Merrill Publishing Company [Freedom to Learn for the examples]. Merrill Publishing Company.

13 Knowles, M.S. (1975). Self-Directed Learning: a Guide for Learners and Teachers. Association Press. New York.

14 Piaget, J. (2004). Psikhologiia intellekta [Psychology of intelligence]. Moscow: Piter [in Russian].

15 Marey, A. Tsifrovizatsiia kak izmenenie paradigmy [Digitalization as a paradigm shift]. [n.d.]. Retrieved from https://www.bcg.com/ru-ru/about/bcg-eview/digitalization.aspx.pdf [in Russian].

16 Sobolev, A.B. (2018). Meniaisia ili ukhodi. Tsifrovoe obrazovanie brosaet vyzov prepodavateliam vuzov [Change your clothes or leave. Digital education challenges university teachers]. Electronic newspaper «Poisk», Vol. 1-2. Retrieved from http://www.poisknews.ru/theme/edu/31969/pdf [in Russian].

17 Kalanova, Sh.M. (2009). Natsionalnaia sistema i obrazovatelnye standarty vysshego obrazovaniia v Respublike Kazakhstan. Obrazovatelnye standarty vyshego obrazovaniia v Respublike Kazakhstan. Natsionalnyi doklad [The national system and educational standards of higher education in the Republic of Kazakhstan. Educational standards of higher education in the Republic of Kazakhstan]. National report, 2nd Ed., reprint. and add. Moscow [in Russian]. 